Authors' Accepted Version: Sturdy Colls, C. (In Press). The Heart of Terror: A Forensic and Archaeological Assessment of the Old Gas Chambers at Treblinka. In: Vareka, P. and Symonds, J. Dark Modernities. Basingstoke: Palgrave Macmillan.

\title{
THE HEART OF TERROR: A FORENSIC AND ARCHAEOLOGICAL ASSESSMENT OF THE OLD GAS CHAMBERS AT TREBLINKA
}

\begin{abstract}
At the extermination camp at Treblinka in Poland, the Nazis murdered between 900,000 to one million people. When they abandoned the camp in 1943, they tried to hide the traces of their crimes. This resulted in the popular perception that the camp had been destroyed and no systematic attempt was made to locate the evidence of the crimes or to find the graves of the victims. However, this paper will outline how historical and archaeological research has demonstrated that a considerable amount of evidence from the camp does survive. The results of search for the first (old) gas chambers at Treblinka will be outlined and it will be demonstrated how, through the use of a range of interdisciplinary state-of-the-art techniques, a more accurate picture of the camp is emerging. The implications of this work for enhancing education, commemorative and visitor experiences will also be discussed.
\end{abstract}




\section{THE HEART OF TERROR: A FORENSIC AND ARCHAEOLOGICAL ASSESSMENT OF THE OLD GAS CHAMBERS AT TREBLINKA}

\section{INTRODUCTION}

'the longish, not too large brick building, standing in the middle of the death camp, had a strange fascination for me: this was the gas chamber'(Krzepicki 1979)

In 1942, Operation Reinhard was developed by the Nazi Party as a means to eliminate the Jewish population in the General Government district of Poland. Central to the implementation of this policy was the construction of three extermination camps - Bełżec, Sobibor and Treblinka. These camps were to be distinctly different from other types of camps that already existed elsewhere in Europe in that their sole purpose was mass murder. They eventually became places where predominantly Jews but also members of other minority groups (Roma, Sinti and so-called "political prisoners") from all over Europe were murdered in large numbers (Berger 2013; Arad 1987).

The construction of Treblinka extermination camp - around $100 \mathrm{~km}$ northeast of Warsaw began in May 1942. Its location was selected based on its good transport links, the concealment provided by the surrounding landscape and the fact that an labour camp ran by the SS had already been operating successfully as a place of mass violence for over a year (Sturdy Colls forthcoming; Łukaszkiewicz 1947). The extermination camp was located $2 \mathrm{~km}$ away from the existing labour camp. Despite only operating for just over a year, the atrocities perpetrated in Treblinka extermination camp accounted for the majority of the overall death toll of 900,000 to one million people. Unlike the labour camp, the extermination camp had no accommodation barracks for inmates, except those used to house people who were forced to 
dispose of the victims' corpses and sort their belongings. During its most efficient periods, the majority of people sent there were killed within 15 to 20 minutes of arrival after having their personal belongings removed from them. They were then made to walk naked to an area of the camp known as the death camp (Sturdy Colls and Branthwaite 2015; for example testimonies see Wiernik 2015; Bomba 1996; Willenberg 1989; Krzepicki 1979).

The construction of purpose-built gas chambers was what allowed so many people to be murdered at Treblinka. At its peak, 10-12,000 people were killed every day. Many people also died in the trains in which they were deported to the camp, whilst others were shot upon arrival (Rajzman 1989). Their bodies were buried in mass graves and, later, they were cremated on pyres near to the gas chambers.

The final killings at Treblinka extermination camp took place in autumn 1943 but operations had already been downscaled following a revolt by the prisoners on the $2^{\text {nd }}$ August (Webb and Chocholatý 2014; Chrostowski 2004). The revolt saw around 200 of the men that worked in the camp (sorting victims' belongings, removing the corpses from the gas chambers, burying and burning the bodies etc.) escape, although less than half of them survived the war (Arad 1987; Glazar 1999). The revolt also resulted in damage to many of the camp buildings, including the gas chambers which, along with the other camp buildings and infrastructure, were reportedly demolished completely in order to hide all traces of the crimes that had been perpetrated. A farmhouse was constructed at the site of the camp bakery and dairy, and a Ukrainian guard posted there in order to act as a deterrent to those passing through the site and the impression that the area had been nothing but a farm (Zabecki 1977). By November 1943, the camp had been completely levelled. 
In the past, the apparent absence of physical evidence - particularly relating to the gas chambers - has prompted many responses. It has often been argued that the camp must have been totally destroyed by the Nazis and, as such, the absence of physical traces has been seen as proof that the perpetrators were successful in hiding all traces of their crimes (Sturdy Colls 2014). The fact that post-war investigators came to Treblinka to search for evidence and found few traces have been seen as further proof of this (Central Commission for the Investigation of German Crimes in Poland 1946; Łukaszkiewicz, 1946). As a result, it has been assumed that the only information concerning the functioning of the camp and the apparatus of mass murder that will ever be available comes from witness testimony and documentary sources. The belief that the gas chambers, and indeed other evidence, did not survive at Treblinka was in fact so strong that no further in-field investigations took place at the site until the one proposed by the author which is the main focus of this paper. Consequently, Holocaust deniers have used the lack of physical evidence - again particularly of the gas chambers' existence - to argue that they never existed and that Treblinka was nothing but a transit camp (e.g. Hunt 2014; Mattogno and Graf 2004).

This paper will outline the results of the search for the first (old) gas chambers at the extermination camp at Treblinka as they stand to date. This search formed part of a larger evaluation of Treblinka's landscape - which included an assessment of the extermination and labour camps, and other sites with a relationship to them. However, the results of the rest of this investigation are presented elsewhere (Sturdy Colls forthcoming; 2016; 2015a and b; 2014). This paper will demonstrate how a non-invasive forensic and archaeological approach permitted the location of the old gas chambers to be determined and some of the remnants of them to be unearthed. 


\section{PREVIOUS INVESTIGATIONS AT TREBLINKA EXTERMINATION CAMP}

In Sturdy Colls (2014) it was demonstrated how post-war investigations (or lack thereof) have also contributed to claims that all of the surviving evidence pertaining to the extermination camp has been found and that the remainder has been entirely destroyed. It was also demonstrated that neither point is true. Investigations at Treblinka in the immediate aftermath of the war were limited in both scope and duration. The extermination and labour camps were examined first by the Soviet forces, who carried out a cursory examination of the former and excavated three mass graves and some individual graves at the latter (Report of $24^{\text {th }}$ August 1944 , USHMM RG-22.016). This was followed by an investigation by the Central Commission for the Investigation of German Crimes in Poland who spent just a few days carrying out measured survey, test excavations and interviews in relation to both camps (Łukaszkiewicz 1947; 1946). At the extermination camp, although these investigators recorded the presence of human remains, remnants of structures and an abundance of other material remains across the camp areas, this information did not make its way into popular narratives. The investigation was also terminated early in consideration of the oncoming autumn, the present rainfall and the necessity of a rapid conclusion of the judicial preliminary investigations' (Wojtczak 1975, 185).

The site remained neglected and subject to looting until 1959, when the decision was taken to construct a memorial (Muzeum Walki i Męczeństwa w Treblince 2017; Kopówka and Tołwioski 2007). Between 1959 and 1961 this monument, designed by Adam Haupt, Franciszek Duszeńko and Franciszek Strynkiewiecz, was constructed, fundamentally altering the landscape (Radecka 2011). The monument comprises 17,000 stones symbolizing Jewish matzevot (headstones) and represents the towns and villages from which the victims came (Muzeum Walki i Męczeństwa w Treblince 2017). The concrete into which these stones are 
set is purportedly located over the mass graves and cremation pits (pers. comm. Edward Kopówka). A large obelisk, bearing a relief of tortured souls, a large memorial stone bearing the words 'Nigdy Wiecej' (Never Again) and a symbolic cremation pit were also built, which form the centre of memorial services at the site. The creation of the memorials further contributes to the notion of a sterilised landscape where the Nazis managed to hide all traces of their crimes. In addition, the large obelisk resulted in the belief that this was placed over the location of the gas chambers - indeed this is a statement that many tour guides tell visitors. As no remains of the gas chambers were found during construction of the monument, this added to the theory that these structures were completed removed by the Nazis.

\section{METHODOLOGY}

In the absence of detailed investigations and on the basis that it was believed that crimes on such a scale could not so easily be erased, an archaeological project was proposed that would seek (amongst other things) to locate the gas chambers at Treblinka. In developing the methodology for use at Treblinka extermination camp, it was important to consider the following:

- The location of the gas chambers within the area of the former extermination camp was unknown. Although the rough area of the death camp (the section of the camp in which the gassings and mass burials took place) was known, this still accounted for a considerable area. Therefore, a search methodology needed to be developed which allowed large sections of land to be examined.

- The locations of the mass graves and pits into which cremated remains were buried were not known. As Halacha Law forbids the disturbance of (Jewish) human remains that have 
been buried in a grave, it was not initially possible to excavate in the terrain of the former camp (Sturdy Colls 2015, ch. 3; Schudrich 2014).

- The full extent to which the Nazis had attempted to hide their crimes at Treblinka was not known, nor was the extent to which the site had been disturbed by the post-war construction of the memorial or looting. Therefore, it was unclear what condition in which remains would survive and at what depth they would be.

Therefore, the methodology employed at Treblinka to search for the gas chambers has drawn on the latest developments in non-invasive archaeology in order to account for these issues. Narratives concerning Treblinka to date have relied almost exclusively on documentary evidence. However, to do so is to ignore the wealth of other evidence that existed and continues to exist in situ at the site. Additionally, there now exists a broad range of complementary historical and scientific methods that can assist in the examination of these various types of evidence. The methodology employed has drawn up the latest methods and techniques from a variety of different disciplines including archaeology, history, forensic investigation, geography, anthropology, digital humanities, engineering, and computer science. The methods employed ranged from non-invasive through to archaeological test pits. The non-invasive methods allowed a fuller picture of the whole landscape of the camp to be provided and a detailed analysis of various types of evidence to be carried out. When confirmatory excavations were necessary, these were targeted using the information derived from non-invasive survey and, thus, they were minimally invasive and adhered to Halacha Law. These only took place once the locations of the aforementioned mass graves and cremation pits had been determined using non-invasive methods, thus they could be avoided. 
The methodology included:

Detailed desk-based investigation using archival, documentary, photographic, cartographic and video evidence. Documentary evidence from archives included (but was not limited to) administrative documents, official reports, letters, diaries and court transcripts. Many interviews with survivors, perpetrators and witnesses were also examined, as were plans, drawings and artworks created by these individuals. Desk-based investigation relating to the post-war development of the site was also carried. Landscape changes were researched and mapped.

Aerial reconnaissance - Detailed analysis of both historic and modern aerial imagery was undertaken to identify features visible from the air that may indicate the presence of surface or buried remains. Additionally, an airborne LiDAR survey was commissioned. The latter measures the distance of returned pulses of laser light in order to create digital elevation models (DEM) of landscapes and features (Opitz and Cowley 2013; Liu and Mason 2009). The subtle changes in the topography of the ground surface that can be visualised using this method can be indicative of surface and buried remains; hence this represents a useful method to map surviving traces of camp landscapes that span large or complex areas (in terms of topography and obstructive ground cover). At Treblinka, a model of the $3.75 \mathrm{~km}^{2}$ area of the extermination and labour camps was created.

Non-intrusive field investigations - Drawing on the results of the historical research phase and winthropping techniques borrowed from forensic archaeology (Hunter et al 2013), the most likely locations of the camp structures and mass graves were determined and then subject to reconnaissance surveys. This was followed by close contact, systematic walkover survey 
across targeted areas. This allowed surface remains to be identified and recorded using highly accurate GPS and a Total Station. In forensic archaeological search, walkover survey is often carried out to identify the presence of any vegetation change, depressions or other signs of ground disturbance on the basis that these may be indicative of the presence of buried remains (Hunter et al 2013; Hochrein 2002). Disturbance to the ground caused by the excavation and backfilling of a hole and the burial of human remains, objects and structures will all result in changes to the nature and extent of vegetation that grows in a particular area. Equally, the settling of the soil used to backfill or conceal this disturbance or burial will result in visible depressions, mounds or cracks in the landscape (also known as compaction and sedimentation as described by Hochrein 2002. See also Sturdy Colls 2015, ch.6). A combination of subsurface geophysical methods (including Ground Penetrating Radar, resistance survey and electrical imaging) and topographic elevation survey were then employed to record aboveand below-ground evidence and disturbances that may indicate the presence of further remains (Sturdy Colls 2015, ch. 6-7).

Archaeological excavation - Based on the results from the above methodologies, targeted test-pit excavations were undertaken using forensic archaeological techniques in line with the Standards and Guidelines of the Chartered Institute for Archaeologists (2014). These excavations avoided the areas found to contain mass graves (during the non-invasive field investigations stage) and instead focused on locating and characterising physical evidence connected to structures and other material traces of the camp itself. All excavation was completed by hand and each context and cut found was recorded and photographed individually, alongside any objects found within. All of the material was sieved to ensure that small artefacts and bones were recovered. Following the excavation, all geological material 
was placed back into the trench whilst all objects were archived with the Museum of Struggle and Martyrdom in Treblinka.

Data assimilation - Using specialist software, Geographic Information Systems (GIS) and other forms of digital data presentation, it was possible to assimilate the various types of data collected both from archives and in the field (Sturdy Colls 2015, ch. 6-7). This effectively allowed the various layers the sites' history to be visualised and compared.

Dissemination - In order to share the results of the project with a broad audience, various publications (Sturdy Colls forthcoming; 2016; 2015; 2014; Sturdy Colls and Branthwaite 2017), television documentaries (Smithsonian Channel 2015; Channel 5 2014), several exhibitions (including one which engaged with artists who responded to the archaeological findings) (Sturdy Colls and Branthwaite 2017; 2015) and many public outreach events were developed.

\section{FINDING THE OLD GAS CHAMBERS}

\section{$\underline{\text { Witness Information and Other Primary Sources }}$}

At Treblinka, it was reported by witnesses that initially three gas chambers operated within one building (known later as the old gas chambers) and then a further ten chambers were built in another building (known as the new gas chambers) in August 1942 (Wiernik 2015). Given the limitations of space, the search for the old gas chambers will be the focus of this paper.

Only a limited number of people witnessed the old gas chambers first-hand and survived. Of those that did, several provided accounts concerning what they witnessed and provide an 
insight into how the gas chambers looked, where they were located and how they operated. Some survivors have provided maps, models and drawings that provide further visual insights (see Wiernik 2015; Sturdy Colls 2012; Sereny 1995; Glazar 1999; Willenberg 1989; Łukaszkiewicz 1946 for some examples). Unfortunately, no blueprints of the old gas chambers have survived and only one photograph that may show this building is thought to exist.

Jankiel Wiernik stated of the old gas chambers:

'A gas chamber measured $5 \times 5$ meters and was about 1.90 meters high. The outlet on the roof had a hermetic cap. The chamber was equipped with a gas pipe inlet and a baked tile floor slanting towards the platform. The brick building which housed the gas chambers was separated from Camp No. 1 by a wooden wall. This wooden wall and the brick wall of the building together formed a corridor which was 80 centimeters taller than the building. The chambers were connected with the corridor by a hermetically fitted iron door leading into each of the chambers. On the side of Camp No. 2 the chambers were connected by a platform four meters wide, which- ran alongside all three chambers' (Wiernik 2015, 15).

Abraham Krzepicki was able to view the interior of the chambers:

'I saw before me a room which was not too large. It looked like a regular shower room with all the accoutrements of a public bathhouse. The walls of the room were covered with small, white tiles. It was very fine clean work. The floor was covered with orange terracotta tiles. Nickel-plated metal faucets were set into the ceiling' (Krzepicki 1979, 105). 
Both the old and new gas chambers are said to have been the only buildings located within the death camp area that were constructed from brick. All witnesses agree that both the old and new gas chambers were located at the end of the Himmelstrasse ("the road to heaven"), along which victims were herded towards the chambers, although there is some disagreement about their exact location. According to witnesses, the old gas chambers were located further south than the new chambers.

Unfortunately, no aerial photographs exist from when the extermination camp was in operation. However, when the plans drawn by those with access to the extermination area are compared to aerial photographs of the site from 1944, it is evident that the gas chambers could not have been located under the modern memorial obelisk (Sturdy Colls 2012). In fact, they must have been located much further away from the railway platform given the distances between the reception and the death camp referred to by witnesses and the ground scarring visible in the aerial images.

Regarding the demolition of the old gas chambers, witnesses suggest that they were demolished to ground level and that the 'gassing engines and all other metal materials were sent to Lublin' (Webb and Chocholatý 2014, 117).

\section{Locating the Gas Chambers}

Walkover, topographic and LiDAR survey of the former extermination camp area revealed the presence of a number of depressions that indicated that the ground had been disturbed and which suggested that buried remains could be present (Sturdy Colls 2015; 2012; Figure 1). The largest of these depressions was located in the south of the former extermination area 
within the "interest zone" identified as part of the desk-based assessment as being a possible location for the gas chambers. A small number of brick fragments were also observed in this area, partially buried in the topsoil. This was deemed significant as witnesses indicate that the only buildings in the death camp area to be constructed from brick were the gas chambers, as mentioned above.

Figure 1: LiDAR survey results (main image) and Ground Penetrating Radar (GPR) results (bottom right) from Treblinka extermination camp showing features that was eventually revealed as being related to the old gas chambers (Copyright: GeoInformation Group and Centre of Archaeology, Staffordshire University)

Furthermore, the probable presence of buried remains in this area was confirmed by the Ground Penetrating Radar (GPR) and resistance survey of the extermination camp. Underneath the depression observed in the topographic survey, the GPR recorded the presence of a roughly rectangular feature measuring approximately $22 \mathrm{~m} \times 15 \mathrm{~m}$. The feature was visible in the GPR depth profiles from approximately $0.4 \mathrm{~m}$ to $2 \mathrm{~m}$ (Figure 1). Based on the highly reflective nature of the remains, they appeared to be consistent with structural remains. However, given their apparent thickness and spread it seemed likely that they would relate to a partially demolished structure surrounded by rubble. Indeed, it appeared from the other GPR imagery that much of the former camp area was covered with buried debris. The locations of this apparent structures were then evaluated in the context of the other features identified during the non-invasive survey of the former extermination camp area, which included the camp boundaries, the Lazarett (fake field hospital) and mass graves (described in detail in Sturdy Colls and Branthwaite 2016 and 2015; Sturdy Colls 2016; 2014; 2012). This suggested that this structure could plausibly be the old chambers given its location. As outlined above, witnesses state that the old gas chambers comprised of three individual 
sections which measured $5 \mathrm{~m} \times 5 \mathrm{~m}$ each with a connecting corridor. Hence, the overall dimensions of the feature identified in the GPR survey, along with its orientation, also seemed to support this theory.

\section{Examining the Old Gas Chambers}

On the basis that the non-invasive survey resulted in the identification several possible mass graves in the terrain of the former camp that could subsequently be avoided, permission to excavate in the area believed to contain the old gas chambers was granted in 2013. In order to avoid unnecessary disturbance to the memorial area and the buried remains, these excavations were minimally invasive. The aim of the excavations was to characterise the exact nature of the features identified during the geophysical survey to confirm whether they were associated with the old gas chambers.

\section{Trench 1}

The first trench to be excavated in this area was a $1 \mathrm{~m} \times 1 \mathrm{~m}$ test pit located within the $22 \mathrm{~m} \times$ $15 \mathrm{~m}$ geophysical anomaly discussed above (Figure 1). The earliest deposit in this trench was a layer of brown yellow sand (6005) that was identified across the base of the trench. A small keyhole trench was excavated through this to a depth of $0.5 \mathrm{~m}$ (totalling $1.45 \mathrm{~m}$ below present ground level). Building material fragments were recovered from (6005) as well as a metal bolt. This layer was sealed by a further sand deposit (6004) that was $0.10 \mathrm{~m}$ in thickness. Further artefacts were recovered from this layer including significant amounts of building rubble, red and yellow tiles, and plaster (Figure 2). At a depth of $0.85 \mathrm{~m}$, large stone blocks and bricks were encountered that represents the remains of a structure or building 
foundations. Several of the stones were bonded together, whilst others were not in their original positions. Several stones were running into the trench sides suggesting that this feature is much larger than what is represented in this small trench. Associated with these stones were many complete, near complete, and fragments of floor or wall ceramic tiles both red and yellow in colour. Several had concrete on the underside; others had a symbol that included a star and the letters D and L imprinted on the underside (Figure 2). These remains were sealed by a sequence of sandy deposits $(6003,6002$, and 6001) that all contained a huge number of artefacts including further examples of building materials and tiles, plastering crosses, metal tools, plaster and concrete as well as an array of personal items including combs, buttons, dentures and false teeth, earrings, hair clips, pottery and brooches (Figure 2).

Figure 2: Objects and building materials found in Trenches 1 and 2 in association with the foundations of the old gas chambers at Treblinka extermination camp (Copyright: Centre of Archaeology, Staffordshire University)

\section{Appearance and Operation of the Old Gas Chambers}

Witnesses allude to the fact that the old gas chamber building was modelled on a bathhouse/Jewish mikveh with white tiled walls and a floor that was 'covered with orange terracotta tiles' (Krzepicki 1979, 104). The discovery of the orange and yellow floor tiles appears to corroborate these accounts (Figure 2). The tiles were made by a company called Dziewulski and Lange. Their headquarters is based in Opoczno in Poland and the company still trades today, though under a different name. This company may also have had an office in Warsaw during the Second World War. The same tiles have been observed in a mikveh in Lublin, a synagogue in Wyszków and in the ruins of the Warsaw Ghetto. It is not yet known whether the tiles at Treblinka were taken from an existing structure (most likely in the 
Warsaw Ghetto) or whether they were transported directly from one of the Dziewulski and Lange factories. Further research is being conducted to determine this.

Following the discovery of sections of wall and bricks, samples were sent for tests to confirm how this building operated. Witnesses suggest that gas was delivered to the old gas chamber by way of a diesel engine (possibly from a Russian tank): "when the chambers had been completely filled, a motor was started which fed exhaust gas into the chamber' (Yeger 1948). Therefore, these tests were designed to confirm whether carbon monoxide was present. Initial results suggest that a high concentration of carbon monoxide was present in the samples and that this was likely as a result of exposure to carbon monoxide, rather than its natural absorption from the air (Uniwersytet Mikołaja Kopernika w Toruniu 2013).

\section{Trench 2}

Trench 2 was located over an anomaly identified during the geophysical and topographical surveys that sat to the west of the area believed to contain the old gas chambers (e.g. to the west of Trench 1 described above). Both the GPR and the resistance surveys revealed a large area of disturbance in this area and a shallow depression was visible on the surface. It was believed that this disturbance could represent demolition rubble relating to the gas chambers, which were thought to be located in this area based on previous archival and geophysical survey (see above). The trench measured $1 \mathrm{~m}$ by $1 \mathrm{~m}$.

The deposits in this trench were characterised by a sequence of horizontal re-deposited sand layers containing significant volumes of building materials, objects, tools and personal belongings as well as frequent human bones and bone fragments (Figure 2). The excavation of this trench ceased at $1.49 \mathrm{~m}$ for safety reasons and undisturbed natural geology was not 
encountered. The earliest deposit at the base of the trench was grey yellow sand (3006) that contained pebble and charcoal inclusions as well as ceramic tiles, whitewashed bricks with concrete, glass fragments, scissors, and pottery to name just a few of the finds. Overlying (3006) was yellow sand layer (3005) that measured $0.14 \mathrm{~m}$ in thickness and also contained charcoal and pebble inclusions. This layer also contained many artefacts including false teeth and dentures, combs, a knife, bullet casings, barbed wire, tiles, glass, a corroded battery and a pendant. In turn (3005) was sealed by $0.64 \mathrm{~m}$ of brown sand (3004). This layer contained further remnants of building materials including bricks, tiles, and a large, burnt wooden plank or cladding. Further building material was recovered from layer (3003) and layer (3002).

All of the above were sealed by sandy subsoil (3001) and topsoil and turf (3000). Layer (3001) also contained small fragments of stone, possibly quartz, likely associated with the construction of the memorial. The trench was backfilled after recording was complete.

\section{Trench 3}

In 2017, another trench was excavated at the eastern end of the feature identified as the old gas chambers in 2013 (Figure 3). Documentary evidence suggested that the eastern end of the old gas chambers housed a room or structure containing a tank engine that was used to supply the carbon monoxide to the gas chambers. Having located the foundations and construction debris from this building in 2010 (via non-invasive means) and 2013 (via the aforementioned excavations), it was already possible to comment on its shape in plan, and the architecture and aesthetic of the building (Sturdy Colls 2016; 2015; 2014; Sturdy Colls and Branthwaite 2016).

Therefore, the purpose of the 2017 excavation was to advance knowledge regarding how this gas chamber operated and the level of destruction inflicted upon the building by the Nazis in 
an attempt to hide the traces of their crimes. All excavation was completed by hand and material was sieved to recover small artefacts and human remains. This trench originally measured $3 \mathrm{~m} \times 2 \mathrm{~m}$ but it was extended to $4.3 \mathrm{~m}$ at the northeast corner of the trench to determine whether any foundations survived in situ on this side of the structure. Figure 3 shows the photogrammetric model created of the excavated trench.

The trench was excavated to a depth of $1.48 \mathrm{~m}$ at the western end and $0.18 \mathrm{~m}$ at the eastern end. This method was necessary given to make the excavation safe and because of the discovery of a large, steeply sloping cut [8002]. This feature sloped from east to west and continued to dive to a deeper level at the western end of the trench; hence, its base was not identified. At a depth of $1.48 \mathrm{~m}$, it became too unstable to dig further. This feature was not prominent on the surface and only became visible at a depth of $0.65 \mathrm{~cm}$. There was though a subtle difference in the topography in the area interpreted as the old gas chambers. The slope was completely devoid of artefacts, fairly compacted and relatively undisturbed.

This slope [8002] appeared to form a bank or large pit edge. Given the shape and size of the feature, as well as the items found adjacent to it, it seems more likely that this feature is a pit edge that was excavated by a machine during the demolition of the old gas chambers. As the depth of the slope exceeds the $0.85 \mathrm{~m}$ depth of the foundations located on the eastern side of the building in 2013, it can be concluded that this excavation resulted in the removal of in situ foundations on this side and went below this original level. This action appears to have resulted the creation of a large void that was then used to dump building materials and other items before the area was levelled and covered in re-deposited sand to further hide the traces of the structure.

The slope cut through an underlying natural (or re-deposited natural) orangey yellow, sand layer (8003). Overlying cut [8002] was a sand backfill deposit (8001). This was composed of 
homogenous mixed light brown sand. This deposit contained numerous artefacts. Several examples of red and yellow ceramic tiles were recovered. These tiles were of the same type as those recovered during the 2013 excavations of the old gas chamber foundations (during which some tiles were found in situ overlaying the foundations of the structure). Along with these, there were examples of concrete flooring, fragments of brickwork and metalwork. This material is consistent with the demolition rubble of the old gas chamber building. The sand deposit into which these items were mixed (8001) is likely to have originated from bulldozed material from elsewhere in the camp or material taken from the quarry specifically for the purpose of levelling the site (see below). Personal belongings, domestic materials and other objects were also found in this layer, along with fragmented human remains, teeth and dentures. The presence of large sections of concrete flooring but the lack of in situ foundations in this area demonstrates that considerable attempts were made to demolish this part of the structure. Certainly this end of the building exhibited more damage at foundation level than the western end that was excavated in 2013.

All of the above layers and materials were sealed by $0.12 \mathrm{~m}$-thick sandy topsoil and turf (8000) that contained numerous artefacts including barbed wire, fragments of building materials, glass and metal objects. The trench was backfilled to match the original profile of the area and re-turfed.

\section{Demolition}

It is clear from the nature of the material found and the in situ foundations in both the 2013 and 2017 excavations that the Nazis attempted to demolish the walls of the old gas chambers but left much of the building materials in the vicinity. The depth of the foundations $(0.85 \mathrm{~m})$ and other small-scale excavations aimed at locating the new gas chambers (described in Sturdy Colls forthcoming) suggests that a large amount of redeposited sand was placed over 
the top of them to mask them from view. Fossils were also discovered, suggesting that the redeposited sand was excavated from a considerable depth and dumped over the site; possibly it came from the nearby quarry and was initially used to build sandbanks around the camp, before being pushed over the demolished buildings (Willenberg 1989). The depth of these features explains why, after the war and since, it was believed that the camp was entirely destroyed. It is also possible that some of the building materials found closer to the surface could also belong to the new gas chambers that are thought to have been located in the vicinity.

\section{Personal Items}

998 individual objects were recovered during the small-scale excavations carried out in 2013 and more than 400 finds were recovered in 2017 from the areas within and surrounding the old gas chambers. A small number of personal belongings were discovered amongst this assemblage, the majority of which belonged to women. Witness testimonies state that women had their heads shaved before entering the gas chambers and their personal belongings were taken from them in the reception area (Bomba 1996). Therefore, the discovery of personal items in this area was unexpected. It seems likely that some of the items were smuggled into the death camp area by the victims because they were of sentimental value. Some witness accounts do suggest that victims had their heads shaved near to or in the gas chambers on occasions when the camp was operating to capacity and this may explain why so many hair clips were found. Others may have found their way into this area when the camp was levelled at the end of 1943. 
Figure 3: A photograph of Trench 3 once excavation was complete (top), and Image-Based Modelling Survey and Stratigraphic 3D Documentation of the same feature (bottom) (Copyright: Centre of Archaeology)

\section{Human Remains}

In the course of the excavations carried out in the death camp, a considerable amount of human remains were encountered. These remains were not buried in mass graves but were scattered remains that had never been buried in a grave. As per the advice of Chief Rabbi Michael Schudrich, the remains were recovered and reburied by a representative from his Office. Although it was not possible to carry out scientific analysis due to the stipulations of Halacha Law (Sturdy Colls 2015, ch.3), it was possible to observe that many of the remains found were not cremated. All of the remains found were fragmented and disarticulated. Some of the remains did exhibit evidence of burning to varying degrees; some were white in colour suggesting prolonged exposure to flames, whilst others were superficially charred, suggesting a short period of exposure at low temperatures. This demonstrates that not all of the remains of the victims at the extermination camp were cremated as documentary sources suggest. A concentration of gold and silver teeth, and dentures were also discovered in the area of the old gas chambers, suggesting that they were removed from victims somewhere in the vicinity. This is consistent with witness accounts. As these remains are also bodily remains, they were also reinterred with the bone fragments that were found.

\section{IMPACT AND FUTURE WORK}

The research and fieldwork undertaken at Treblinka extermination camp has thus far provided a considerable amount of new information concerning the extent and nature of the killing at 
the site, despite the absence of obvious above-ground evidence. The discovery of the foundations and rubble of the old gas chambers, the structure that lay at the very heart of Nazi terror in Treblinka, challenges many of the narratives that have grown up around the site which suggest that the evidence of the camp has all been destroyed. The application of new technology, not available to forensic investigators during or after World War II, has allowed witness testimonies to be confirmed, complementary information about the architecture and operation of the gas chambers to be provided and details about the extent to which the Nazis tried to hide their crimes to be derived. These discoveries, seventy years after the gas chambers were demolished, clearly illustrate the benefits of using archaeological methods in conjunction with traditional forms of historical research. Identifying the location of the old gas chambers also has implications for our understanding of the layout of the rest of the camp and of the killing practices that were being undertaken at Treblinka. The personal objects and human remains found at the site provide a poignant reminder of the victims that the Nazis tried so hard to eradicate. As further research is conducted concerning the discoveries made and the results are compared further to archival material, a more detailed picture of these sites will undoubtedly emerge in the future.

These discoveries have also provided valuable opportunities for commemoration, education and museum display both at Treblinka and elsewhere around the world, thus demonstrating the wider benefits of archaeological investigations at sites of Nazi terror. As already noted, these include international exhibitions, publications, a television documentary, a wide range of educational tools and public outreach activities. Sadly, the archaeological works have not led to the marking of the location of the old gas chambers on the ground due to concerns over further excavations needed to erect signage. Given the depth of the remains and their fragility, they are also not visible to visitors who go to the site. It is hoped in the future that funding 
may become available to reflect the archaeological discoveries on site so visitors may have a better sense of the layout of the camp.

Research relating to Treblinka is ongoing and the results of surveys and excavations at the site of the camp waste pit, new gas chambers and other structural remnants of the camp are still being analysed. This work now forms part of an international, interdisciplinary research project entitled “Accessing Campscapes: Inclusive Strategies for Using Europe's Conflicted Heritage" (iC-ACCESS) which seeks to examine the evidence connected to several Holocaust and Soviet-era campscapes as well as the ways in which this evidence has been, and can be, used for commemoration, education, political purposes and the construction of narratives (by a variety of groups and individuals). The project will also develop a number of digital tools that will further allow the results of the work at Treblinka and other sites to be disseminated to a wider audience. 


\section{REFERENCES}

Arad, Yitzhak (1987). Belzec, Sobibor, Treblinka: The Operation Reinhard Death Camps. Indiana: Indiana University Press.

Berger, Sara (2013). Experten der Vernichtung: das T4-Reinhardt-Netzwerk in den Lagern Belzec, Sobibor und Treblinka. Hamburg: Hamburger Edition HIS.

Bomba, Abraham (1996). Abraham Bomba on Treblinka, http://sfi.usc.edu/tags/abrahambomba. Accessed $14^{\text {th }}$ June 2017.

Central Commission for the Investigation of German Crimes in Poland (1946). German War Crimes in Poland. Volume 1. Warsaw: Central Commission for the Investigation of German Crimes in Poland.

Channel 5 (2014). Treblinka: Inside Hitler's Secret Death Camp, http://www.channel5.com/show/treblinka-inside-hitlers-secret-death-camp/, accessed $14^{\text {th }}$ June 2017.

Chartered Institute for Archaeologists (2014). Standards and Guidance for Archaeological Excavation, $\quad$ https://www.archaeologists.net/sites/default/files/CIfAS\&GExcavation 1.pdf, accessed $14^{\text {th }}$ June 2017. 
Chrostowski, Witold (2004). Extermination: Camp Treblinka. London: Vallentine Mitchell and Co. Limited.

Hochrein, Michael J. (2002). "An Autopsy of the Grave: Recognizing, Collecting and Preserving Forensic Geotaphonomic Evidence' in William Haglund and Marcella H. Sorg (Eds.) Advances in Forensic Taphonomy: Method, Theory and Archaeological Perspectives. Boca Raton: CRC Press, 45-70.

Hunt, Eric (2014). The Jewish Gas Chamber Hoax, https://holocausthandbooks.com/index.php?page $\mathrm{id}=1007$, accessed $14^{\text {th }}$ June 2017.

Hunter, John, Barrie Simpson and Caroline Sturdy Colls (2013). Forensic Approaches to Buried Remains. London: John Wiley and Sons.

Kopówka, Edward and Piotr Tołwiński (2007). Kamienie milczą - ja pamiętam. Siedlce: Muzeum Walki i Męczeństwa w Treblince.

Krzepicki, Abraham (1979). "Eighteen days in Treblinka", in The Death Camp Treblinka: A Documentary, Alexander Donat (Ed.). New York: Holocaust Library, 77-146.

Liu, Jian G. and Philippa Mason (2009). Essential Image Processing and GIS for Remote Sensing. London: John Wiley. 
Łukaszkiewicz, Zdzisław. (1947), "Obóz pracy w Treblince” in Biuletyn Głównej Komisji Badania Zbrodni Hitlerowskich w Polsce, Volume 3. Głównej Komisji Badania Zbrodni Hitlerowskich w Polsce. Warsaw: Wydawnictwo Prawnicze.

Łukaszkiewicz, Zdzisław. (1946). Obóz straceń w Treblince. Warsaw: Panstwowy Instytut Wydawniczy.

Mattogno, Carlos. and Jürgen Graf. (2004). Treblinka: Extermination Camp or Transit Camp? Chicago: Theses \& Dissertations Press.

Muzeum Walki i Męczeństwa w Treblince (2017). http://www.treblinkamuzeum.eu/index.php/historia/oboz-zaglady, accessed 14th November 2017.

Opitz, Rachel and David Cowley (2013). Interpreting Archaeological Topography: 3D Data, Visualisation and Observation. Oxford: Oxbox Books.

Radecka, Katarzyna (2011). The Materials Concerning the Implementation of the Mausoleum of the Victims of the Extermination Camp in Treblinka. Treblinka: ASP Gdańsk.

Rajzman, Samual (1947), in Trial of the Major War Criminals before the International Military Tribunal Nuremberg 14 November - 1 October 1946. Nuremberg. 1945. IMTN (International Military Tribunal). http://www. loc.gov/rr/frd/Military_Law/NT_major-warcriminals.html, date accessed $14^{\text {th }}$ June 2017. 
Schudrich, Michael (2014). "Legal Issues." Paper presented at the IHRA Killing Sites Research and Remembrance Conference, 22nd January 2014, Krakow.

Sereny, Gita (1995). Into that darkness: From Mercy Killing to Mass Murder. London: McGraw-Hill.

Smithsonian Channel (2015). Treblinka: Hitler's Killing Machine, https://www.smithsonianchannel.com/shows/treblinka-hitlers-killing-machine/0/3403868, accessed $14^{\text {th }}$ June 2017.

Sturdy Colls, Caroline (forthcoming), Finding Treblinka: Archaeological Investigations at Treblinka Extermination and Labour Camps.

Sturdy Colls, Caroline (2016). "Earth conceal not my blood': forensic and archaeological approaches to locating the remains of Holocaust victims", in Human remains in society: Curation and Exhibition in the Aftermath of Genocide and Mass-Violence, Dreyfus, JeanMarc and Anstett, Elizabeth. Manchester: Manchester University Press.

Sturdy Colls, Caroline (2015a). Holocaust Archaeologies: Approaches and Future Directions. New York: Springer.

Sturdy Colls, Caroline (2015b). Badania archeologiczne w Obozie Zaglady i Karnym Obozie Pracy w Treblince, in: Treblinka: Historia i Pamięc, Edward Kopówka, Siedlce: Muzeum Walki i Męczeństwa w Treblince. 
Sturdy Colls, Caroline (2014). "Gone but not forgotten: Archaeological approaches to the landscape of the former extermination camp at Treblinka, Poland ", Holocaust Studies and Materials 3, 239-289.

Sturdy Colls, Caroline (2012). Holocaust Archaeology: Archaeological Approaches to Landscapes of Nazi Genocide and Persecution, Unpublished PhD Thesis, University of Birmingham.

Sturdy Colls, Caroline and Michael Branthwaite (2017). "This is proof"? Forensic evidence and ambiguous material culture at Treblinka extermination camp'. International Journal of Historical Archaeology 23. DOI 10.1007/s10761-017-0432-3.

Sturdy Colls, Caroline and Michael Branthwaite (2015). Treblinka: Archaeological and Artistic Responses. Centre of Archaeology Book Series: Special Issue. Amazon Createspace

Uniwersytet Mikołaja Kopernika w Toruniu (2013). Badania Konserwatorskie Ceglanych i Betonowych Obiektów z Dawnego Obozu Pracy I Zagłady w Treblince. Unpublished Report.

Webb, Chris and Michal Chocholatý (2014). The Treblinka Death Camp: History, Biographies, Remembrance. New York: Columbia University Press.

Wiernik, Jankiel. (2015). A Year in Treblinka. Pickle Partners Publishing.

Willenberg, Samuel. (1989). Surviving Treblinka. Oxford: Blackwell. 
Wojtczak, Stanisław (1975). "Karny obóz pracy Treblinka I i ośrodek zagłady Treblinka II", Biuletyn Głównej Komisji Badania Zbrodni Hitlerowskich w Polsce XXVI, 117-185.

Yeger, Aleksander (1948). Stenograph of Testimony of Aleksander Yeger, http://search.nizkor.org/hweb/people/y/yeger-aleksandr-ivanovich/yeger-002.html, accessed $10^{\text {th }}$ Sept 2009.

Ząbecki, Franciszek. (1977). Wspomnienia Dawne i Nowe. Warszawa: Instytut Wydawniczy Pax.

\section{ACKNOWLEDGEMENTS}

Thanks are due to the staff at the Museum of Struggle and Martyrdom in Treblinka, especially Dr Edward Kopówka, for their assistance during the Finding Treblinka project. For their specialist advice about Halacha Law, thanks are due to Chief Rabbi of Poland, Michael Schudrich, Agnieszka Nieradko and Aleks Schwartz. The authors are grateful for the assistance of those involved in the archaeological fieldwork at Treblinka and data postprocessing, especially Ivar Schute, William Mitchell, Dr Dante Abate, Janos Kerti, Czelsie Weston, Laura Thomas, Iwan Witt, Joanna Zasłona, Dr Pavel Vareka and students from the University of West Bohemia. The fieldwork would not have been possible without funding from Staffordshire University, University of Birmingham, Furneaux and Edgar Productions and Channel 5. The 2017 fieldwork was funded by, and formed part of, the "Accessing Campscapes: Inclusive Strategies for Using Europe's Conflicted Heritage" (iC-ACCESS) project, financed by HERA Uses of the Past Call. 